\title{
KONSELING TRAUMA PASCA BENCANA
}

\author{
Herman Nirwana \\ Jurusan Bimbingan dan Konseling FIP Universitas Negeri Padang \\ Korespondensi: Jln. Prof. Dr. Hamka Air Tawar, Padang, Sumatera Barat \\ e-mail: herman.nirwana@yahoo.com
}

\begin{abstract}
As a country with thousands of islands, geographically Indonesia is very potential to natural disasters which cause great lost, environmental damage and psychological effects. Besides, violence, such robbery, rapes, and bombing frequently took place in Indonesia. It is estimated that $1.50 \%$ of population suffered from Post Traumatic Stress Disorder (PSTD) due to the violence. Studies show in America that 15 up to $43 \%$ of females and 14 up to $43 \%$ of males experience trauma in their lives. Great numbers of individuals suffer from deep misery, uncertainty and desperation after natural disaster or violence and in turn leave them in stress, depression and trauma. One of services recommended to help those people go through with psychological problems is counseling, particularly relaxation and desensitization techniques.
\end{abstract}

Kata kunci: trauma, konseling trauma

\section{PENDAHULUAN}

$\mathrm{K}$

ehidupan yang dijalani individu penuh dengan stres tingkat renberhadapan dengan stres yang lebih serius, misalnya gempa bumi, banjir, dan perampokan. Dalam menghadapi stres tersebut, ada individu yang bisa mengatasinya, namun kadangkadang juga tidak sedikit individu yang tidak bisa mengatasinya, sehingga menimbulkan masalah bagi individu. Bisa tidaknya individu mengatasi stres ditentukan oleh tingkat kepercayaan diri dan kemampuan yang dimilikinya (Weaver, Flannelly, dan Preston, 2003). Dengan kata lain, individu yang memiliki kepercayaan yang tinggi dan memiliki kemampuan yang memadai, cenderung bisa mengatasi stres yang dihadapinya.

"Indonesia sebagai negara kepulauan berada pada posisi geografis, geologis, hidrologis, dan demografis yang rawan bencana" (Soemantri, 2012: 1). Dengan demikian, bencana alam sudah menjadi bagian dalam kehidupan penduduk Indonesia, karena kejadian alam di Indonesia hampir setiap hari terjadi. Sebagai contoh adalah terjadinya gempa bumi sedikitnya satu kali dalam sehari. Di samping kejadian alam yang muncul setiap hari, masih ada kejadian alam yang lain seperti tanah longsor, angin putting beliung, banjir, dan letusan gunung berapi. Bencana alam yang terjadi senantiasa mengakibatkan hilangnya nyawa manusia, kerusakan lingkungan, kerugian harta benda, dan berdampak psikologis. Dari data yang ada disimpulkan bahwa: (1) peristiwa bencana secara nasional didominasi oleh bencana angin topan, banjir, kebakaran, kekeringan, dan tanah longsor; dan (2) banyaknya korban meninggal didominasi oleh peristiwa bencana gempa bumi dan tsunami (Soemantri, 2012). 
Bencana alam yang melanda kehidupan seperti sunami, gempa bumi, dan bajir merubah kehidupan manusia yang damai dan bahagia menjadi kehidupan yang sangat menakutkan. Akibat peristiwa tersebut, harta benda hilang dan lenyap seketika, dan tidak sedikit nyawa manusia melayang. Di samping itu, peristiwa kekerasan juga sering terjadi dalam kehidupan, seperti pemboman, pemerkosaan, kecelakaan kapal, peperangan, pembajakan pesawat. Sebanyak 1,50 persen populasi mengalami Post-Traumatic Stress Disorder (PTSD) dalam kurun empat tahun karena mengalami berbagai peristiwa tersebut (Kinchin, 2007).

Hasil penelitian di Amerika memperlihatkan $15-43 \%$ wanita dan $14-43 \%$ pria mengalami peristiwa trauma selama kehidupan mereka. Anak-anak dan remaja yang menglami peristiwa trauma, $3-15 \%$ wanita dan $1-6 \%$ pria mengalami Post Traumatic Stress Disorder (PTSD) (National Center for PTSD, dalam Nilsson, Gustafsson, dan Svedin, 2010). Dari penelitian tersebut terlihat bahwa wanita memiliki resiko lebih tinggi mengalami PTSD dari pria. Di samping itu, penelitian di Swedia juga memperlihatkan 15.5-24.5\% remaja dilaporkan mengalami trauma (Svedin, Nilson, dan Lindell, dalam Nilson, Gustafsson, dan Svedin, 2010).

Peristiwa traumatis menyerang kehidupan manusia secara tiba-tiba, dan mengubah kahidupan manusia menjadi berantakan. Setelah peristiwa tersebut sebagian individu tidak yakin untuk bisa hidup secara baik lagi seperti sebelum terkena bencana atau peristiwa traumatis (Kinchin, 2007). Dengan kata lain, individu atau selamat banyak yang mengalami guncangan berat, stres, depresi, dan trauma setelah bencana. Kondisi ini menjadi ancaman serius bagi kehidupan. Dan menjadi lebih serius lagi atau bahaya bagi anak-anak, pasangan, kerabat dekat, atau teman-teman lainnya (Kinchin, 2007). Mereka membutuhkan layanan untuk kesehatan mental, sta- bilitas emosional, dan optimisme untuk memulai kehidupan baru pasca kehilangan semua yang berarti dalam hidupnya. Karena itu, bantuan berupa layanan konseling trauma merupakan kebutuhan yang tidak kalah penting untuk diprioritaskan.

Ada dua kondisi psikologis yang sangat berat yang dialami oleh para korban bencana yang lolos dari maut. Pertama, mereka menanggung beban psikologis yang tidak ringan karena mereka harus hidup dengan trauma kehilangan sanak keluarga dan orang-orang yang dicintainya. Kehilangan orang yang sangat berarti dalam hidupnya bisa dirasakan sebagai pukulan psikologis yang berat. Tidak semua orang sanggup mengatasi penderitaan dipisahkan secara paksa dari orang-orang yang dicintainya. Di sisi lain, mereka kini juga kehilangan pekerjaan dan akses usaha serta modal untuk melanjutkan hidup.

Kedua, dalam kondisi yang serba sulit itu, mereka harus mampu segera bangkit dan melakukan penguatan diri sendiri, mengambil hikmah dari seluruh musibah itu untuk modal dasar memulai kehidupan baru dari titik nol, bahkan bisa jadi mereka harus memulai dari kondisi minus. Membangun kehidupan yang bermakna, butuh ketegaran jiwa dan keyakinan kuat atas kebesaran Allah dibarengi dengan usaha yang tak kenal lelah.

\section{TRAUMA DAN POST TRAUMATIC STRESS DISORDER}

Penelitian terbaru mengungkapkan bahwa beragam pengalaman yang dialami individu bisa menimbulkan trauma, seperti penculikan, penyerangan, perkosaan, dan menyaksikan pembunuhan anggota keluarga, atau kematian anggota keluarga dekat. Empat belas persen (14\%) individu mengalami trauma setelah ditinggalkan anggota keluarga yang dicintai (Weaver, Flannelly, dan Preston, 2003). 
Trauma merupakan suatu kejadian pisik atau emosional serius yang menyebabkan kerusakan substansial terhadap pisik dan psikologis seseorang dalam rentangan waktu yang relative lama (Weaver, Flannelly, dan Preston, 2003). Sementara trauma psikis dalam psikologi diartikan sebagai kecemasan hebat dan mendadak akibat peristiwa dilingkungan seseorang yang melampaui batas kemampuannya untuk bertahan, mengatasi atau menghindar. Di samping itu, trauma adalah suatu kondisi emosional yang berkembang setelah suatu peristiwa trauma yang tidak mengenakkan, menyedihkan, menakutkan, mencemaskan dan menjengkelkan, seperti peristiwa: pemerkosaan, peperangan, kekerasan dalam keluarga, kecelakaan, bencana alam dan peristiwa-peristiwa tertentu yang membuat batin tertekan (Lawson, 2001; Kinchin, 2007). Trauma psikis terjadi ketika seseorang dihadapkan pada peristiwa yang menekan yang menyebabkan rasa tidak berdaya dan dirasakan mengancam. Reaksi umum terhadap kejadian dan pengalaman yang traumatis adalah berusaha menghilangkannya dari kesadaran, namun bayangan kejadian itu tetap berada dalam memori.

Peristiwa mengerikan yang dialami individu menjadi ingatan yang menghiasi jaringan susunan emosi. Gejala tersebut merupakan tanda amigdala terlalu banyak tergugah sehingga memaksa ingatan yang hidup akan sesuatu peristiwa terus menerus menerobos kesadaran. Setiap peristiwa yang menimbulkan trauma bisa menanamkan ingatan-ingatan pemicu di amigdala, misalnya: selamat dari kapal tenggelam, pemboman, kebakaran, gempa bumi, dirampok, diperkosa, dan lain-lain (Goleman, 1995; Kinchin, 2007). Di antara semua peristiwa itu, peristiwa seperti selamat dari kapal tenggelam, pemerkosaan dan perampokan cen- derung menimbulkan Post Traumatic Stress Disorder (PTSD) pada individu dibandingkan dengan peristiwa berbahaya lainnya (Goleman, 1995; Marotta, 2000; Garrett, dalam Locke, Myers, dan Herr, 2001; Kinchin, 2007). Alasannya, dalam peristiwa tersebut (pemerkosaan dan perampokan) yang menjadi obyek kekerasan hanya individu sendiri, sementara pada peristiwa kekerasan lainnya (misalnya kebakaran dan gempa bumi) obyeknya banyak orang.

Di samping faktor peristiwa, faktor lain yang memicu PTSD adalah ketidakberdayaan individu (Goleman, 1995). Misalnya seorang yang diserang dengan pisau dan ia tahu dan memiliki keterampilan bagaimana cara bertindak untuk membela diri, maka ia tidak akan trauma; sementara individu lain yang tidak mengetahui cara membela diri akan mengatakan "mati aku". Orang yang tidak mengetahui cara membela diri cenderung lebih mudah terkena PTSD.

Berdasarkan penjelasan di atas, bisa disimpulkan anak-anak cenderung lebih mudah terkena PTSD dibandingkan orang tua. Hal ini didasarkan pada kenyataan karena anak-anak kurang memiliki kemampuan dalam menghadapi bahaya dibandingkan dengan orang tua. Dengan kata lain, semakin kecil umur seseorang cenderung tidak mampu dia menghadapi bahaya, dan cenderung semakin besar pula kemungkinannya untuk mengalami PTSD.

Faktor ketiga yang mendorong PTSD adalah fear conditioning (pengkondisian rasa takut (Goleman, 1995), yaitu pengkondisian sesuatu yang awalnya sama sekali tidak ditakuti menjadi sesuatu yang menakutkan bagi individu. Pengkondisian rasa takut ini dilakukan oleh orang dewasa kepada anak-anak. Misalnya, seorang anak usia dua tahun yang takut melihat kucing karena ia pernah dicakar oleh kucing. Setelah 
peristiwa tersebut orangtua selalu menakut-nakuti anaknya dengan memperlihatkan kucing, atau ketika anaknya mendengar suara kucing. Cara-cara seperti itu merupakan pengkondisian rasa takut pada anak, yang pada akhirnya anak akan takut mendengarkan suara kucing, apalagi melihat kucing.

Hampir semua orang yang mengembangkan PTSD dengan emosi yang intens terhadap suatu stimulus yang menyerupai peristiwa traumatis yang dialaminya. Hal ini kemudian diikuti dengan intrusion, yaitu keadaan yang ditandai dengan emosi, pikiran, dan kenangan yang selalu hidup dalam pikiran seseorang sepanjang hari. Gejala ini juga cenderung menimbulkan mimpi buruk, sehingga individu juga takut tidur. Pada akhirnya, kurang tidur akan berdampak pada peningkatan emosional yang akan mendorong individu untuk mengonsumsi alkohol, atau bunuh diri. Gejala lain individu yang mengalami trauma berat cenderung menarik diri dari interaksi sosial. Di samping itu, gejala umum individu yang mengalami PTSD adalah selalu tegang dan gelisah, mudah terkejut, lekas marah, depresi dan penyalahgunaan obat, sesekali melukai diri sendiri, halusinasi, susah tidur, penurunan berat badan, sering sakit kepala, dan gangguan seksual (Weaver, dkk. 2003).

Bila dikaitkan penjelasan sebelumnya dengan pandangan behavioristik, maka perilaku traumatis terbentuk melalui pengalaman belajar, terutama fear conditioning yang dilakukan oleh lingkungan. Perilaku individu merupakan hasil dari pengalamannya (George dan Cristiani, 1995; Hock, 1999), dan dengan demikian perilaku traumatis yang dialami individu merupakan hasil belajar atau produk pengalamannya. Oleh sebab itu untuk menghilangkan perilaku traumatis atau perilaku salah suai lainnya juga dihilangkan melalui pengalaman belajar (relearning).

\section{KONSELING TRAUMA}

Layanan konseling trauma pada prinsipnya dibutuhkan oleh semua korban selamat yang mengalami stres dan depresi berat, baik itu orang tua maupun anak-anak. Anak-anak perlu dibantu untuk bisa menatap masa depannya dan membangun harapan baru dengan kondisi yang baru pula. Bagi orang tua, layanan konseling trauma akan membantu mereka memahami dan menerima kenyataan hidup saat ini; untuk selanjutnya mampu melupakan semua tragedi dan memulai kehidupan baru.

Di samping untuk menstabilkan kondisi emosional, layanan konseling trauma bagi orang tua idealnya juga memberikan keterampilan yang dapat dijadikan modal awal memulai kehidupan baru dengan pekerjaan-pekerjaan baru sesuai kapasitas yang dimiliki dan daya dukung lingkungan. Dengan demikian, mereka bisa sesegera mungkin menjalani hidup secara mandiri sehingga mereka tidak terus-menerus menyandarkan kehidupannya pada orang lain, termasuk pada pemerintah. Untuk mencapai efektivitas layanan, konseling trauma dilakukan dengan dua format, yaitu format individual (untuk korban yang tingkat stres dan depresinya berat), dan format kelompok (untuk individu yang beban psikologisnya masih pada derajat sedang).

Sebelum pelaksanaan layanan konseling diberikan, langkah pertama adalah menciptakan rasa aman (Weaver, dkk. 2003). Bagi individu yang mengalami trauma, dunia ini dirasa tidak aman dan nyaman. Oleh sebab itu, mereka memerlukan orang lain yang bisa memberikan perlindungan dan rasa nyaman pada mereka, sehingga mereka merasa tidak sendirian dalam hidup ini. Penciptaan rasa aman teresebut bisa dilakukan dengan mengadakan permainan yang bisa mendorong individu untuk melupakan sejenak peristiwa traumatis yang dialaminya. Bagi individu yang mengalami 
trauma karena perampokan di tempat kerja, penciptaan rasa aman bisa dilakukan dengan memberi izin untuk tidak masuk kerja dalam beberapa hari; dan bagi yang kena rampok di rumah, bisa dilakukan dengan pindah rumah buat sementara.

Pendekatan klasikal bisa diterapkan untuk kasus-kasus yang berhubungan dengan rasa takut yang tidak adaptif (Prawitasari, 2011). Salah satu teknik yang digunakan secara luas bagi klien yang mengalami masalah kecemasan karena peristiwa traumatis adalah disensitisasi sistematik (Holden, dalam Locke, Myers, dan Herr, 2001; George dan Cristiani, 1995). Prawitasari (2011: 159) menyebutnya dengan istilah "nirpeka beraturan". Teknik ini didasarkan atas prinsip classical conditioning. Asumsi dasar yang mendasari teknik ini adalah bahwa semua perilaku individu terbentuk melalui pengalaman atau hasil belajar, dan untuk mengubah, memodifikasi atau menghilangkan perilaku tersebut juga melalui belajar. Oleh sebab itu, responsi terhadap kecemasan itu bisa dipelajari atau dikondisikan (Wolpe, dalam Hock, 1999), dan proses ini disebut dengan terapi (Corey, 2012).

Sebelum disensitisasi dimulai, konselor melakukan konseling untuk mengetahui informasi spesifik tentang kecemasan klien guna memahami latar belakang diri klien secara komprehensif. Konselor harus mengidentifikasi gejalagejala trauma atau PTSD yang dialami oleh klien (Lawson, 2001) dengan menanyakan kepada klien tentang kondisi atau peristiwa khusus yang memicu rasa takut tersebut. Hal ini bisa dilakukan jika klien merasa nyaman, dan rasa nyaman itu diciptakan oleh konselor.

Setelah penyulut kecemasan terdeteksi, konselor bersama klein menyusun daftar urutan situasi yang menyulut kecemasan dalam bentuk hirarki, mulai dari situasi yang menimbulkan kecemasan rendah sampai tinggi (Wolpe, dalam Hock, 1999; Holden, dalam Locke, Myers, dan Herr, 2001). Jumlah tahapan atau hirarki urutan kecemasan yang disusun tergantung pada tingkat kecemasan yang dialami klien, biasanya sampai lima, enam, atau lebih (Wolpe, dalam Hock, 1999). "Dalam teknik ini, klien dilatih dulu untuk relaksasi kemudian secara bertahap relaksasi ini dipasangkan dengan situasi yang menakutkannya sampai akhirnya ia dapat mengatasi rasa takutnya" (Prawitasasi, 2011: 159).

Proses disensitisasi dimulai dengan menyuruh klien duduk dalam keadaan santai dan nyaman sambil memejamkan matanya. Teknik ini disebut latihan rileksasi, yaitu proses penegangan dan pengenduran berbagai otot, seperti lengan, tangan, wajah, perut, kaki, dan lain sebagainya (Wolpe dalam Hock, 1999). Setelah klien merasa rileks, ia diminta untuk membayangkan sesuatu yang paling sedikit menimbulkan kecemasan sesuai dengan hirarki yang telah disusun. Apabila klien masih bisa santai dalam membayangkan peristiwa tersebut, konselor bisa bergerak maju dalam hirarki selanjutnya sampai klien memberi isyarat bahwa pada situasi itulah dia mengalami kecemasan, dan pada saat itu pula skenario dihentikan (Wolpe, dalam Hock, 1999). Klien disuruh membuka matanya dan disuruh duduh santai.

Apabila klien tidak bersedia melanjutkan pada hirarki kecemasan yang lebih tinggi, konselor bersama klien membahas secara mendalam apa yang dialaminya, atau melanjutkannya pada konseling berikutnya. Sebaliknya bila klien bersedia melanjutkan konseling, pengendoran ketegangan dimulai lagi dan dilanjutkan dengan hirarki kecemasan yang lebih tinggi lagi. Kon- 
seling dihentikan manakala klien sudah tidak mengalami kecemasan lagi. Dengan demikian, pada klien yang mengalami PTSD yang tinggi, teknik disensitisasi cenderung dilakukan berulang-ulang.

\section{PENUTUP}

Berdasarkan uraian terdahulu bisa disimpulkan bahwa banyak individu yang mengalami trauma dalam kehidupannya, apalagi bagi masyarakat Indonesia yang rawan tertimpa bencana. Peristiwa yang menimbulkan trauma bagi individu di antaranya perampokan, pemerkosaan, kecelakaan, kebajiran,

\section{DAFTAR RUJUKAN}

Corey, G. 2012. Theory \& Practice of Group Counceling. Belmont, CA: Brooks/ Cole.

George, R.L. dan Cristiani, T.S. 1995. Counseling: Theory and practice. Needham Heights, Massachusetts: Allyn and Bacon.

Goleman, D. 1995. Emotional Intelligence. New York: Bantam Books.

Hock, R.R. 1999. Forty Studies That Changed Psychology. Upper Saddle River, New Jersey: Prentice-Hall, Inc.

Kinchin, D. 2007. A Guide to Psychological Debriefing. London: Jessica Kingsley Publishers.

Lawson, D.M. 2001. The Development pf Abusive Personality: A Trauma Response. Journal of Counceling \& Development, 79. 505-509.

Locke, D.C.; Myers, J.E.; dan Herr, E.L. (Eds.). (2001). The Handbook of Counseling. Thousand Oaks, California: Sage Publications.

Marotta, S.A. 2000. Best Practices for Councelors Who Treat Post- gempa bumi, dan sunami. Jika dibandingkan antara pria dan wanita, ternyata wanita lebih banyak yang mengalami trauma. Di samping itu, wanita lebih beresiko mengalami PostTraumatic Stress Disorder (PTSD).

Banyaknya individu yang beresiko tinggi mengalami PTSD setelah peristiwa trauma mengindikasikan mereka sangat membutuhkan layanan konseling trauma. Oleh sebab itu, kepada konselor disarankan untuk memberikan layanan konseling trauma melalui penciptaan rasa aman, dan konseling perorangan dengan penggunaan teknik desensitisasi sistematis yang didahului dengan teknik rileksasi.

traumatic Stress Disorder. Journal of Counceling \& Development, 78, 492-495.

Nilson, R.; Gustafsson, P.E.; dan Svedin, C.G. 2010. Self-ReportPotentially Traumatic Live Events and Symptoms of Post-Traumatic Stress and Dissociation. Nordic Journal of Psychiatry. 64, 19-26.

Prawitasari, J.E. 2011. Psikologi Klinis: Pengantar terapan mikro \& makro. Jakarta: Penerbit Erlangga.

Soemantri, H. 2012. Strategi Pengarasutamaan Pengurangan Resiko Bencana Di Sekolah. Makalah disajikan dalam Rapat Kooordinasi Tim Pengembangan Kurikulum Propinsi dan Kabupaten/Kota Se Indonesia, Tanggal 23-26 Juli di Hotel Mercure Ancol Jakarta.

Weaver, A.J., Flannelly, L.T., dan Preston, J.D. 2003. Counseling Survivors of Traumatic Events: A handbook for pastors and other helping professional. Avenue South, Nashville: Abingdon Press. 
Indeks

bencana

$123,124,125,128$

trauma ............123, 124, 125, 126, 127, 128

konseling

$123,124,126,127,128$

traumatis

$124,125,126,127$

konselor

$.127,128$ 